المجلة الدولية للدراسـات التربوية والنفسية

International Journal of Educational \& Psychological Studies (EPS)

Journal Homepage: https://www.refaad.com/views/EPSR/Home.aspx

www.refaad.com

ISSN: 2520-4149 (Online) 2520-4130 (Print)

\title{
Personality Traits and their Relationship to Some Variables in Orphan Children in the West Bank
}

\author{
Nahida Saba Al Arja \\ Assistant Professor, Psychological counseling, Social Sciences Department, Bethlehem University, Palestine \\ narja@bethlehem.edu
}

Received Date : $17 / 3 / 2020$

Accepted Date : $19 / 4 / 2020$

DOI : https://doi.org/DOI:10.31559/EPS2020.7.3.8

\begin{abstract}
Family cohesion and the presence of parents play a critical role in the lives of children living in an environment that helps the healthy psychological development of children and the integration of their personalities. The present study aims to identify the personality traits of orphan children and to ascertain the impact of selected demographic variables on major personality traits. A random sample of 172 orphans responded to the Eysenck Personality Questionnaire (EPQ). The results showed a statistically significant variance due to gender in neuroticism in favor of females, between lying and living in an institution, and between neuroticism and both parents and in lying the differences were in favor of the father. The city variable revealed differences in favor of extroversion in Jerusalem; neuroticism in Nablus and lying in Bethlehem.
\end{abstract}

Keywords: personality traits; orphan children; West Bank/OPT.

\section{Introduction}

Being a pre-adolescent orphan is quite critical because children at this stage are usually in a serious need for parental and family care as it plays an essential role in the psychosocial forming of their personalities and is crucial for their psychosocial compatibility within the changing circumstances surrounding them. According to George (2011) an orphan is "a child who is below 18 years of age and who has lost one or both parents." The family is the cradle of society where children find the proper natural environment where they grow up and go through the different stages of their development. Ideally, the family setting provides a child with a balanced upbringing that is free from behavioral or psychological problems. The family also provides the child with a perspective through which the child learns society norms, codes, restrictions and taboos allowing him to be able to interact with other people outside his immediate environment. (Abu Shamala, 2002)

Orphan children often suffer from a number of mental illnesses and disorders due to tension, anxiety, anger and insecurity. They may also endure a lack of self-confidence resulting from their loss of parental support as well as a lack of social recognition and sense of belonging. In contrast, life in a social welfare institution, due to its inherent nature, deprives orphans of the normal family setting and is characterized by its monotony and tends to be dull and unexciting, and completely different from the normal family atmosphere, which is dominated by closeness, intimacy and love. Children in orphanages (or welfare institutions) are also deprived of the opportunity for socialization as they live within the physical limits and restrictions of the institution, which orphans have to abide by. (Faqihi, 2006) Undoubtedly, deprivation of parental and family care represents an emotional trauma that impacts a child's life very negatively, causing personality disorders, especially in childhood, being the most important development stage. A welfare institution cannot provide an adolescent child with his/her emotional needs and neither can it train him in the various types of social and emotional behavior (Huwaywah, 2016). The family plays a role in shaping the personality of the individual through the process of social normalization (Hassouna, 2002).

One of the simplest and oldest methods of describing personality is to identify the patterns of behavior that characterize a person and call him by the feature that characterizes him most. According to some researchers such features are considered dispositional characteristics i.e. tendencies of behavior or responses which a person is expected to transfer from one situation to another, and that involve a certain probability that a person might behave in a certain way (Lazaus, 1989). Other researchers, however, consider these features as summary or 
descriptive-situational factors, i.e. that describe a coherent or similar set of behaviors or responses to different situations and at different times (Al-Ansari, 1997).

The existence of multiple definitions of personality may be attributed to the difficulty of considering personality as a whole entity. Yet, in spite of this multiplicity, the following seems to be the most comprehensive and generally accepted definition of personality: "the characteristics or blend of characteristics that make a person unique" (Weinberg \& Gould, 1999)

Psychologists are interested in identifying the psychological traits or qualities that have relative stability (such as generosity, kindness, anxiety, indifference, recklessness, etc.) and which distinguish one individual from another; in other words, traits which exhibit individual differences in the availability of an attribute, trait or a measured or measurable characteristic and not in kind only.

When conflict surfaces between the various aspects of personality, disorder and poor harmony arise, leading in some cases to what is known as a helpless personality (physically or mentally). Consequently, an individual may lose their ambition and ability to adapt, and often fails to pursue their studies or achieve their goals. The social environment also plays an important role in shaping the personality of a child.

Trait theory is characterized by allowing measurement and experimentation, in addition to observation and description. Accordingly, personality can be measured by a number of personal dimensions and measurements, ultimately helping the development of a personality (psychological) profile (Mansi, 2001)

Trait theory aims to investigate and measure personality as it utilizes the statistical method, particularly factor analysis. It also views personality as a dynamic system/ combination/ composition of an array of traits, which are considered to be the primary mover of behavior. Eysenck, Albort and Catel are the most significant advocates of trait theory. (Abdallah, 2001)

Eysenck used factor analysis, a technique which reduces behavior to a number of factors which can be grouped together under separate headings, or dimensions. Eysenck (1947) found that their behavior could be represented by two dimensions: Introversion / Extroversion (E); Neuroticism / Stability (N). Eysenck called these second-order personality traits. Each aspect of personality (extraversion, neuroticism and psychoticism) can be traced back to a different biological cause. Personality is dependent on the balance between excitation and inhibition processes of the autonomic nervous system (ANS). (McLeod, 2017)

When a child is born, it lacks experience, knowledge and ability to behave socially. It receives its first experience in social/human relationship from its family in general, and from its parents in particular. This contributes to the formation of a child's balanced personality, and its awareness of itself and the social environment, which ensures positive communication with others, including any required adjustment according to mutual positive and relationships. (Halawa, 2011)

The family is one of the most important social factors that contribute to the formation of the personality of children, and has an even greater role in the different aspects of psychological compatibility or incompatibility of the individual. The cohesion of the family and the presence of parents play a major role in the lives of children, creating an atmosphere that helps the healthy psychological development of the children and the harmony and integration of their personalities. (Dasouki, 1996)

Children are particularly vulnerable to traumatic experiences, such as divorce or death. The absence of parents usually deprives the child of a strong relationship that provides him with love, security and care, and hinders his or her natural development and creates an unbalanced and fluctuating personality. (Rabi', 2001)

The deprivation of young children from family care is a case that is worthy of research because of its negative impact on a child's development and behavior. (Anani, 2000) Orphan children usually require assistance and support from the surrounding community, individuals or institutions, to provide a suitable psychological and social atmosphere that is essential for the young orphan's various stages of development. There are several social institutions that support orphans in the West Bank.

Research indicates that children who are deprived of family environment suffer most from bad behavior, neuroticism and depression. Ismail (2009) show that the problems that individuals who are deprived of a family life suffer from are extraversion, neuroticism, depression, and emotional symptoms in the first place, and to a lesser extent, a lack of friends and hyperactivity.

To the best of our knowledge, very little research has been conducted on how personality traits of orphan children in Palestine are affected by a number of variables. It is hoped that the present research will fill this research gap.

The main goal of this study is, therefore, to identify the personality traits of orphan children and to identify the differences in these traits according to the following variables: gender, educational level, place of residence, orphan status, current place of residence (with family or in an institution). 


\section{Methods}

\section{Participants and Procedures}

The study sample consisted of 172 orphans (14-18 years), living with their families or in a social institution. All were attending school in Bethlehem, Hebron, Nablus or Jerusalem districts.

\section{Materials}

\section{Eysenck Personality Questionnaire}

An Arabic version of The Eysenck Personality Questionnaire for Children (male and female) was used to collect the data for the present study. (Abdel-Khalek,1991) The questionnaire battery, which includes a consent form and a demographic information sheet, has 59 yes/no questions that measure, extroversion, neuroticism and lying. For each item, a yes answer is rated 1 point, while a no answer is rated zero. Cronbach's Alpha reliability of The Eysenck Personality Questionnaire for Children (male and female was in Neuroticism: (0.616) and Extroversion (0.633), Lying (0.719) denoting good internal consistency and temporal stability. The descriptive analytical method in this study was adopted in order to answer the questions and assumptions presented by the study.

\section{Analysis}

Data analysis and sample size calculations were performed using the Statistical Package for Social Sciences Software (SPSS, version 19).

\section{Results}

The findings of the present study of the total sample of participants $(n=172)$ reveal that the degree of the personality traits of orphan children among West Bank students scored are neuroticism with an average of (13.20) and a standard deviation of (3.02) followed by extroversion with an average of (12.91) and a standard deviation of (3.35). The least trait was lying with an average of (10.77) and standard deviation of (3.70).

Table (1): Mean, standard deviation of personality traits of orphan children in the West Bank

\begin{tabular}{|l|c|c|c|}
\hline \multicolumn{1}{|c|}{ Dimension } & Mean & Std & Ratio \\
\hline Extroversion & 12.91 & 3.02 & $68 \%$ \\
\hline Neuroticism & 13.20 & 3.35 & $66 \%$ \\
\hline Lying & 10.77 & 3.70 & $54 \%$ \\
\hline
\end{tabular}

- Gender:

Table (2) It is clear that there were statistically significant differences in the total degree between males and females in regard to neuroticism and the absence of differences in Extroversion and Lying. The significance level was (.039) in favor of females, whose mean was (13.65) compared to (12.58) for males.

Table (2): Results of t-test for variance in total means of the personality traits of orphan children in regard to gender

\begin{tabular}{|l|l|c|c|c|c|c|c|}
\hline Dimension & Gender & Number & Mean & Std & T value & $\begin{array}{c}\text { Degree of } \\
\text { freedom }\end{array}$ & $\begin{array}{c}\text { Level of } \\
\text { significance }\end{array}$ \\
\hline \multirow{2}{*}{ Extroversion } & Male & 72 & 13.36 & 2.62 & 1.68 & 170 & .094 \\
\cline { 2 - 8 } & Female & 100 & 12.58 & 3.25 & & & .039 \\
\hline \multirow{2}{*}{ Neuroticism } & Male & 72 & 12.58 & 3.90 & -2.08 & 170 & .473 \\
\cline { 2 - 6 } & Female & 100 & 13.65 & 2.83 & & & \\
\cline { 2 - 6 } & Male & 72 & 10.53 & 2.84 & -.71 & 170 & \\
\cline { 2 - 5 } & Female & 100 & 10.94 & 4.22 & & & \multicolumn{2}{|c}{} \\
\hline
\end{tabular}

- Residence: home vs. institution:

Table (3) It is clear that there were statistically significant differences in the total degree between Institution and home in regard to Lying, and the absence of differences in Extroversion and Neuroticism. The level of significance was (.001) in favor of the institution whose mean was (15.00) while that of the home was (10.56) 
Table (3): Results of t-test for variances in total means of personality trait according to type of residence

\begin{tabular}{|c|c|c|c|c|c|c|c|}
\hline Dimension & $\begin{array}{c}\text { Residence } \\
\text { type }\end{array}$ & Number & Mean & Std & $\mathrm{T}$ value & $\begin{array}{c}\text { Degree of } \\
\text { freedom }\end{array}$ & $\begin{array}{c}\text { Level of } \\
\text { significance }\end{array}$ \\
\hline \multirow[t]{2}{*}{ Extroversion } & Home & 164 & 12.95 & 3.05 & \multirow[t]{2}{*}{.870} & \multirow[t]{2}{*}{170} & \multirow[t]{2}{*}{.385} \\
\hline & Institution & 8 & 12.00 & 2.07 & & & \\
\hline \multirow[t]{2}{*}{ Neuroticism } & Home & 164 & 13.22 & 3.38 & \multirow[t]{2}{*}{.283} & \multirow[t]{2}{*}{170} & \multirow[t]{2}{*}{.777} \\
\hline & Institution & 8 & 12.88 & 2.90 & & & \\
\hline \multirow[t]{2}{*}{ Lying } & Home & 164 & 10.56 & 3.64 & \multirow[t]{2}{*}{-3.412} & \multirow[t]{2}{*}{170} & \multirow[t]{2}{*}{.001} \\
\hline & Institution & 8 & 15.00 & 2.07 & & & \\
\hline
\end{tabular}

\section{- City:}

Table 4 shows statistically significant differences in the personal characteristics of the orphan children in the West Bank due to the city of residence. A Tukey test was used to identify these differences. The findings showed differences regarding extroversion between Jerusalem and the other governorates in favor of Jerusalem. For neuroticism, the differences between Bethlehem, Jerusalem and Nablus were in favor of Nablus. Regarding lying, the differences were in favor of Bethlehem. The mean of the Jerusalem scored (16.71) where the significance level reached .000, and (14.47) for Nablus where the level of significance was (.001) while Bethlehem scored (12.83) and the level of significance was (.000).

Table (4): One Way Anova analysis of the differences in the degree of personality trait dimensions among orphan children

\begin{tabular}{|l|l|c|c|c|c|c|}
\hline \multicolumn{1}{|c|}{ Dimension } & \multicolumn{1}{|c|}{ Source } & $\begin{array}{c}\text { Sum of } \\
\text { squares }\end{array}$ & $\begin{array}{c}\text { Degree of } \\
\text { freedom }\end{array}$ & $\begin{array}{c}\text { Squares } \\
\text { Mean }\end{array}$ & F Value & $\begin{array}{c}\text { Level of } \\
\text { significance }\end{array}$ \\
\hline \multirow{4}{*}{ Extroversion } & Between groups & 232.523 & 3 & 77.5 & 9.835 & 0.000 \\
\cline { 2 - 7 } & Inside groups & 1323.989 & 168 & 7.8 & & \\
\cline { 2 - 7 } & Total & 1556.512 & 171 & & & \\
\hline \multirow{5}{*}{ Leuroticism } & Between groups & 181.127 & 3 & 60.3 & 5.840 & 0.001 \\
\cline { 2 - 7 } & Inside groups & 1736.751 & 168 & 10.3 & & \\
\cline { 2 - 7 } & Total & 1917.878 & 171 & & & \\
\cline { 2 - 7 } & Between groups & 325.913 & 3 & 108.6 & 9.041 & 0.000 \\
\cline { 2 - 7 } & Inside groups & 2018.785 & 168 & 12.01 & & \\
\cline { 2 - 7 } & Total & 2344.698 & 171 & & & \\
\hline
\end{tabular}

\section{- Orphan status:}

Table 5 shows statistically significant differences in the personal characteristics of orphan children in neuroticism and lying due to the variable of orphan status. A Tukey test was used to identify these differences. The findings showed that in neuroticism the differences between the father and the mother were in favor of both parents and in lying the differences were in favor of the father. The mean of both parents scored (14.88), where the level of significance was (.014). The mean of the father was (11.28), where the level of significance reached (.000)

Table (5): One Way Anova analysis of the differences in the degree of personality trait dimensions among orphan children regarding orphan status

\begin{tabular}{|l|l|c|c|c|c|c|}
\hline Dimension & \multicolumn{1}{|c|}{ Source } & $\begin{array}{c}\text { Sum of } \\
\text { squares }\end{array}$ & $\begin{array}{c}\text { Degree of } \\
\text { freedom }\end{array}$ & $\begin{array}{c}\text { Squares } \\
\text { Mean }\end{array}$ & F Value & $\begin{array}{c}\text { Level of } \\
\text { Significance }\end{array}$ \\
\hline \multirow{4}{*}{ Extroversion } & Between groups & 25.511 & 2 & 12.7 & 1.436 & 0.241 \\
\cline { 2 - 7 } & Inside groups & 1421.594 & 160 & 8.8 & & \\
\cline { 2 - 7 } & Total & 1447.104 & 162 & & & \\
\hline \multirow{4}{*}{ Neuroticism } & Between groups & 94.260 & 2 & 47.1 & 4.399 & .014 \\
\cline { 2 - 7 } & Inside groups & 1714.219 & 160 & 10.7 & & \\
\cline { 2 - 7 } & Total & 1808.479 & 162 & & & \\
\hline & Between groups & 212.260 & 2 & 106.1 & 8.311 & .000 \\
\cline { 2 - 7 } & Inside groups & 2043.188 & 160 & 12.7 & & \\
\cline { 2 - 7 } & Total & 2255.448 & 162 & & & \\
\hline
\end{tabular}




\section{Discussion:}

The results revealed that there were statistically significant differences in neuroticism in favor of the females, which means that the females are more eager, anxious and depressed than the males and also indicate that they are more vulnerable to suffering from neurosis. The high degrees of individuals on the neuroticism dimension indicate emotional instability and exaggerated emotional responses. They also find it difficult to regain balance after an exciting experience.

This result is due to the fact that a child who has lost one of his parents, especially girls, may feel a loss of that parent's tenderness, kindness and their sense of safety, which makes them more tense than the males, as the males have a wider opportunity to express their feelings and emotions more directly in society; while females tend to suppress their feelings and emotions, and this surfaces as neuroticism. Women also reveal a greater sensitivity to pressure on others, and are called on more often to provide emotional support than men (Meichenbaum, d.1994)

The results of this study are in agreement with the results of (Abu Warda, 2011) and the results of (Latorre et al.1993), which indicated a higher level of neuroticism in females than males. However, the results of the current study conflict with those of (Ismail ,2009) and (Shatat 2000) which found that males scored higher than females on neuroticism.

It was also found that there were statistically significant differences in lying among orphan children in the West Bank due to the current place of residence in favor of the institution and no differences regarding extroversion and neuroticism were found. This explains why a child residing in an institution is inclined to fake his degree on the personality test. It is suggested that a child who resides in a welfare institution and who is consequently deprived of his family environment resorts to lying for a variety of reasons, including a feeling of inferiority and pressure to defend himself for fear of punishment by others since he has no parents who would provide him with protection, and also to obtain gains he may be deprived of in the accommodating institution (Malikiya and Bojman, 2016). An orphan child in this context tends to lie and pretend to have a more socially appropriate appearance. In this regard, (Khammash, 2007) emphasizes the importance of this dimension and points out that it varies from one society to another, and it involves civilizational and cultural variables. This is consistent with (Huwaywah 2015). Yet these results are inconsistent with (Al-Shamali ,2015) who showed no statistically significant differences between orphan children who enjoy family care and those living in institutions.

There were also statistically significant differences in the personality traits of orphan children in the West Bank due to the city variable. To find out the source of the differences, a tukey test was used for dimensional comparison. The results show that differences regarding extroversion between Jerusalem and the other governorates (i.e. Bethlehem, Hebron and Nablus) were in favor of Jerusalem, but concerning neuroticism, the differences were in favor of Nablus and in regard to lying, the differences were in favor of Bethlehem. Extroversion indicates that children in Jerusalem are sociable, impulsive, and have an affinity for fun, vitality, joy, wit and optimism. This may be attributed to the nature of life in the Palestinian society in terms of the political and economic conditions. City life provides better living conditions than the village. The city provides the opportunity for people to participate in a variety of cultural, recreational and sporting activities; while movement in the city is much easier than the village.

As for neuroticism, the results showed statistically significant differences in favor of the city of Nablus, which means that children in the city of Nablus are more anxious, worried and depressed than the children in Jerusalem, Hebron and Bethlehem. The high personal degrees in regard to neuroticism indicate emotional instability and exaggerated emotional response. They also find difficulty regaining balance after an exciting experience. A person with a high degree of neuroticism can be described as someone who is inclined to have a lot of anxiety. (Bunamaki ,1988) indicates that cultural and social differences have an impact on the perception and evaluation of stressful events and that each society has its distinct circumstances, beliefs and culture, which affect an individual's perception of pressure, and the way he confronts such situations which is based on his interaction with the family and social environment and the impact of social norms and values and the surrounding social and political reality. The results of the present study are consistent with the results of (Chung, et al.,1999), which showed that Coventry residents lacked sociability and were neurotic, which was attributed to the relationship between assault, intrusion, neuroticism and extroversion.

On the lying dimension, the differences between Bethlehem, Jerusalem, and Nablus were in favor of Bethlehem, where children were more inclined to pretend to be better than they are. According to (Khammash ,2007) societies vary there is variation from one society to another with regard to this dimension., and also indicated that civilizational and cultural variables of society should be taken into account when dealing with this dimension. For example, orphan children in Bethlehem live in a different environment from orphans living in the city of Jerusalem and Nablus. 
It was also found that there were statistically significant differences in neuroticism and lying among orphan children in the West Bank due to orphan status. To find out the source of the differences, a Tukey test was used for dimensional comparisons. The results were as follows:

On the neuroticism dimension, the differences between the father and mother were in favor of the loss of both parents. It is suggested here that a child is born with certain needs and requires physical, psychological, emotional and linguistic contact with his parents, and when this contact is broken due to the loss of one or both parents, the child is likely to develop certain personality disorders. According to the theory of emotional contact, individuals who suffer from personality disorders tend to have a fragile and weak relationship with their caregivers early in their lives, and consequently, certain strange and unacceptable events occur between the two parties leading to certain medical problems or disorders. (Al-Tahan, Abu Attia, 1998). (Ballan ,2011) also mentioned that the father and mother are jointly responsible for raising their children in terms of providing guidance, encouragement, acceptance, ways to build their self-confidence, and consolidation of values. Yet, the loss of either or both parents constitutes the most serious source of deprivation and negatively impacts the child's personality and behavior and makes him feel inferior and deprived of sympathy and affection, while his ability to face the pressures and problems of life is seriously weakened, and this makes the orphan child sad and anxiety. The death of the parents constitutes a threat to the child's personality and mental health, which is sometimes only achieved if the parents are present or live in a normal family, and the deprivation of the child from his parents leads to the existence of psychological and social problems that may accrue to him the negative effects in the later stages of his life (Al-Suwaihri, 2009).

The results regarding lying reveal differences in favor of the father. The researcher believes that a child who loses the father is more inclined to fake a better status, and this finding is consistent with (Huwaywa , 2015), as a child who is deprived of his family environment is quite likely to resort to lying for several reasons, including a feeling of inferiority and his defense of himself for fear of punishment by others as a result of the parents who, in a normal situation, would protect him; as well as for personal gain, which he has been deprived of in the residential establishment. This is consistent with (Huwaywa 2015) who indicates that lying is a prevalent behavioral problem among children residing in an institution.

\section{References:}

[1] Abdallah. Mohammad Qassem, An Introduction to Mental Health. Dar Al-Fikr Li-Attiba'ah wa-Al-Nashr wa-AlTawzii', Amman, Jordan, (2001).

[2] AbdElKhalek. A., The Eysenck Personality Questionnaire for Children, Dar Al-Marefa, Alexandria, Egypt, (1991).

[3] Abu Shammaleh. A., The Relationship of the Methods of Care in Orphanages to Psychosocial Compatibility, Unpublished MA Thesis, University of Gaza, Gaza, (2002).

[4] Abu Wardeh. S., Some Personality Traits of Tenth and Eleventh Grade Beaten Students in Hebron District, Unpublished MA Thesis. Al-Quds University, Jerusalem, (2001).

[5] Al-'Anani. Hanan, Children, Family and Society, Dar Al-Safaa' li-An-Nashr wa-Al-Tawzii'Amman, Jordan, (2000).

[6] Al-Ansari. B., Characteristic Traits of Male and Female Kuwaiti Youth. Paper presented at the Fourth International Conference of Psychological Counselling. Ein Shams University, Cairo, Egypt. In the Arab Journal for Human Sciences, 15(59) (1997), 53-88.

[7] Al-Shamali. Nidal, The Relationship of the Five Personality Factors to Distress of Patients at Gaza Community Center, Gaza Program for Mental Health. Unpublished MA Thesis, Islamic University, Gaza, (2015)

[8] Al-Suwaihiri. Ali, Psychosocial Problems of Orphans of the Society of Orphans in Mecca, Saudi Arabia. MA Thesis, Umm Al-Qura University, (2010).

[9] Al-Tahhan. Mohammad \& Abu 'Atiyyeh. Siham, Counselling Needs of Al-Hashimiyyah University Students, Dirasat, Journal of Psychological and Educational Sciences, 29(1) (2002), 129-155. https://www.ajsrp.com > jeps > article

[10] Ballan. K., Theories of Psychological Counselling 2, Damascus University, Faculty of Education Publications., Syria, (2011).

[11] Chung. C. et al., The relationship between trauma and personality in victims of the Boeing 737- 2 D6C crash in Coventry, Journal of Clinical Psychology, 55(5) (1999), 617-629, https://doi.org/10.1002/(sici) 10974679(199905)55:5\%3C617::aid-jclp9\%3E3.0.co;2-2

[12] Dasouki. Rawiya, M., The Relationship of Parental Deprivation to Psychological Compatibility and the Concept of Self and Distress for University Students. Journal pf Psychology. Year 10, 40 October (1996).

[13] Eysenck. H. J. \& Eysenck. S. B., Manual of the Eysenck Personality Questionnaire, San Diego: Educational and Industrial Testing Service, (1991). 0493-10504 
[14] Faqihi. Mohammad, Behavioral Problems of Adolescents Deprived of Family Care in Saudi Arabia, MA Thesis. Naif Arab University for Security Sciences, Riyadh, Saudi, (2006).

[15] Halawah. B., The Role of Parents in their Children's Social and Personality Development, Damascus University Journal, 27(4) (2011), 109-171, doi: www.damascusuniversity.edu.sy

[16] Hassouneh. Thafer, Personal Traits and Other Features of Tenth Grade /Students in UNRWA and Government Schools in the District of Irbid, MA Thesis, Yarmouk University, Jordan, (2002), http://repository.yu.edu.jo:80/jspui/handle/123456789/5851

[17] Huwaywah. Malika, Behavioral Problems of Children Deprived of Family Care from the Perspective of Teachers. University of Mohamed Khider, Biskra, Algeria, Unpublished MA Thesis, (2015).

[18] Ismail. Y., Behavioral Problems of Children who are Deprived of Family Environment, Unpublished MA Thesis. Islamic University, Gaza, (2009).

[19] Khammash. Ahmad, Personality Dimensions of Students of Vocational Diploma in the Gaza Strip and their Relation to Certain Variables, MA Thesis, Islamic University, Gaza, (2007), https://iugspace.iugaza.edu.ps > bitstream > handle > file_1

[20] Lawrence. L. f. \& Bennett, Treatment of Extreme Shyness, Association of Educational Psychologists, Journal psychologists, vol, 6(2) (1992), $64-69$.

[21] Lazarus. Richard, Personality, (Translated by S. Ghuneim. Dar Al-Shurouq, Beirut, Cairo, (1989).

[22] Mansi. Hassan, Mental Health, (Second edition) Dar Al-Kindi li-Al-Nashr wa-Al-Tawzii', Jordan, (2001).

[23] McLeod. S. A., Theories of personality, (2017), Retrieved from https://www.simplypsychology.org/personalitytheories.html25-46

[24] Meichenbaum. D., A clinical handbook/ Practical therapist manual for assessing and treating adults with posttraumatic stress disorder (PTSD), Waterloo, Ontario: Institute Press, (1994).

[25] Mikhaylova. Yu., Development of emotional regulation in pupils of children's home from birth to 4 years, Thesis. Moscow: Moscow Lomonosov State University Lomonosov, (2004), p. 225

[26] Owaidah. Kamel, Personality Psychology, Dar Al-Kutob Al-'Alamiyyah, Jordan, (1996).

[27] Punamaki. Raya Lina, the mental health of Palestinian children and women under the Israeli occupation, translated by Louis Malika in Readings in Social Psychology in the Arab World, Cairo, Volume VI: The Egyptian General Book Authority, (1988).

[28] Rabi'. Mohammad, Efficiency of Group Treatment of Separation Anxiety and Loneliness for a Group of Residents of Accommodation Institutions, Doctoral Dissertation, Ein Shams University, Egypt, (2001).

[29] Shatat. Suha, Psychological construction of the Personality of Orphan Children, MA Thesis, Faculty of Education, Islamic University, Gaza, (2000).

[30] Shulga. T.I. \& Tatarenko. D.D., Psychological characteristics of adolescent orphans who have no experience of socialization in the family, Psychological Science and Education, 2(2013), 203-213

[31] Tatyana. I. Shulgaa. Daria D. Savchenkoa \& Evgeniya. B. Filinkovaa, Psychological Characteristics of Adolescents Orphans with Different Experience of Living in a Family, International Journal of Environmental \& Science Education, 11(17) (2016).

[32] Tottenham. N, Hare. T.A., Millner. A., Gilhooly. T., Zevin. J.D. \& Casey. B.J., Elevated Amygdala Response to Faces Following Early Deprivation. Developmental Science, 14(2) (2011),190-204, https://doi.org/10.1111/j.14677687.2010.00971.x

[33] Weinberg. R. S., \& Gould. D., Personality and sport. Foundations of Sport and Exercise Psychology. Human Kinetics; 6 edition, November 1, 2014. 


$$
\text { المجلة الدولية للدراسـات التربوية والنفسية }
$$

International Journal of Educational \& Psychological Studies (EPS)

Journal Homepage: https://www.refaad.com/views/EPSR/Home.aspx

\section{سمات الشخصية وعلاقتها ببعض المتغيرات لدى الأطفال الأيتام في الضفة الغربية ناهدة سـابا العرجا \\ أستاذ مساعد في الإرشاد النفسي- قسم العلوم الاجتماعية- جامعة بيت لحم- فلسطين narja@bethlehem.edu}

يلعب التماسك الأسري ووجود الوالدين دورًا حاسمًا في حياة الأطفال الذين يعيشون في بيئة تساعد على النمو النفسي الصبي للأطفال ودمج شخصياتهم. تهدف الدراسة الحالية إلى التعرف على السمات الشخصية للأطفال الأيتام والتأكد من تأثير المتغيرات الديموغرافية المختارة على السمات

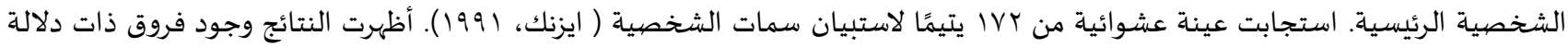

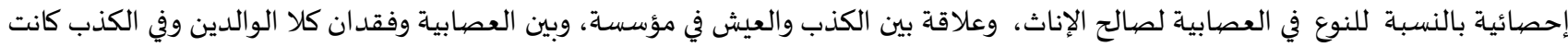
الاختلافات لصالح الأب. كشف متغير المدينة عن اختلافات لصالح الانبساط في القدس، والعبه العصابية في نابلس والكذب في بيت لحم. 